\title{
Observations on 10 years' HBs antigenaemia after renal transplantation
}

\section{J NAGINGTON}

From the Public Health Laboratory Service, Level 6, Laboratory Block, Addenbrooke's Hospital, Cambridge CB2 2QW, UK

SUMMARY A renal transplant patient became a carrier of $\mathrm{HBs}$ Ag within four weeks of a successful transplant. The level of antigenaemia was extremely high, and approximately $3 \%$ of the particles were $42 \mathrm{~nm}$ Dane particles, although anti-HBe was present from at least 20 months after transplant.

After four years the antigenaemia declined to a low level, and five years later HBs Ag became undetectable for the first time. During the past 18 months no antigen has been detected although immunosuppression continues and the original kidney is still functional.

It has been possible to record in detail a renal transplant patient with HBs antigenaemia from before the onset until the cessation of carriage while he remained on immunosuppression and retained the transplanted kidney for 12 years.

\section{Case report}

A man aged 35 received a cadaver kidney on 6 August 1968 which was rejected and removed on 9 September 1968. After bilateral nephrectomy on 14 October 1968 he was given a second cadaver kidney on 9 November 1968. He became a carrier by 5 December 1968 and his level of antigenaemia was subsequently found to be very high. His renal function recovered well and he was discharged on 24 December 1968, since when he has remained well with good renal output. His early history was recorded in $1970 .^{1}$

\section{Methods}

The extent of HBs antigenaemia was initially measured by the complement fixation test (CFT) which was replaced by the introduction of the reverse passive haemagglutination test (RPHA) in 1974. ${ }^{2}$ The RPHA test (Hepatest, Wellcome Reagents Ltd) titres are about two- to four fold higher than those of the CFT with this patient, which compares well with observations on other ad subtype carriers. ${ }^{3}$

The radioimmunoassay test (RIA) used was Ausria II (Abbot Laboratories Ltd).

Accepted for publication 10 September 1980
The proportion of $42 \mathrm{~nm}$ HBs antigen (Dane) particles was derived from counts made on electron micrographs of centrifuged antigen in serum samples, as previously described, 1 and from 1973 onwards antiserum had to be added to concentrate the antigen. 4

The anti-HBc test used was counter-immunoelectrophoresis. ${ }^{5}$ RIA tests for anti-HBc were undertaken by Dr DS Dane, Middlesex Hospital, who was also able to demonstrate anti-HBs in the 1979 sample by means of RIA.

\section{Results and discussion}

The patient already had anti-HBc by 5 July 1968, before his first transplant on 6 August 1968, so it is likely that his liver was already infected and that his antigenaemia was the result of immunosuppression after the second transplant on 9 November 1968, that is, he had reactivation or recrudescence of existing infection and not a primary infection. ${ }^{6}$

Antigenaemia was found within 26 days of the second transplant on 9 November 1968 and reached a very high blood level (approx. $10^{11}$ particles $/ \mathrm{ml}$ ), which was maintained for 4 years. During this time the patient was symptomless although his liver function tests were abnormally high (Table).

Approximately $3 \%$ of the antigen particles were $42 \mathrm{~nm}$ (Dane) particles so that his serum was potentially highly infectious, and it is probably very fortunate that dialysis was not required during this time.

We have been unable to establish his $\mathrm{HBe}$, anti$\mathrm{HBe}$ status for the first 21 months because the sera 
Summary of $\mathrm{HBs}$ antigen titres, anti-HBc, and anti-HBe in relation to immunosuppressive drug dosage and liver function

\begin{tabular}{|c|c|c|c|c|c|c|c|c|c|}
\hline \multirow[t]{2}{*}{ Year } & \multicolumn{3}{|c|}{ HBs Ag一maximum titre during year } & \multirow{2}{*}{$\begin{array}{l}42 \mathrm{~nm} \text { (Dane) } \\
\text { particles } \%\end{array}$} & \multirow{2}{*}{$\begin{array}{l}A n t i \\
-H B c\end{array}$} & \multirow{2}{*}{$\begin{array}{l}\text { Anti } \\
-H B e\end{array}$} & \multicolumn{2}{|c|}{ Immunosuppression dosage } & \multirow{2}{*}{$\begin{array}{l}\text { Liver function: } \\
A L T(U / I)\end{array}$} \\
\hline & $C F T$ & $R P H A$ & $R I A$ & & & & $\begin{array}{l}\text { Prednisolone } \\
\text { (mg/day) }\end{array}$ & $\begin{array}{l}\text { Azathioprine } \\
\text { (mg/day) }\end{array}$ & \\
\hline $\begin{array}{l}1968 \\
1969 \\
1970 \\
1971 \\
1972 \\
1973 \\
1974 \\
1975 \\
1976 \\
1977 \\
1978 \\
1979 * \ddagger \\
1980 \dagger\end{array}$ & $\begin{array}{r}<8 \\
8000 \\
4000 \\
4000 \\
1000 \\
16 \\
64 \\
8 \\
<8 \\
" \\
" \\
" \\
"\end{array}$ & $\begin{array}{l}\text { ND } \\
\text { ND } \\
16000 \\
\text { ND } \\
\text { ND } \\
\quad 64 \\
64 \\
32 \\
32 \\
16 \\
<8 \\
", \\
\quad "\end{array}$ & $\begin{array}{l}\text { ND } \\
\text { ND } \\
\text { ND } \\
\text { ND } \\
\text { ND } \\
\text { ND } \\
\text { ND } \\
\text { ND } \\
\text { ND } \\
+ \\
+ \\
- \\
-\end{array}$ & $\begin{array}{r}1 \\
3 \\
" \\
<\ddot{1} \\
", \\
" \\
\text { ND" } \\
\text { ND } \\
\text { ND } \\
\text { ND }\end{array}$ & $\begin{array}{l}+ \\
+ \\
\text { ND } \\
\text { ND } \\
\text { ND } \\
\text { ND } \\
\text { ND } \\
\text { ND } \\
\text { ND } \\
+ \\
+ \\
+ \\
+\end{array}$ & $\begin{array}{l}\text { NA } \\
\text { NA } \\
+\S \\
\text { ND } \\
\text { ND } \\
\text { ND } \\
\text { ND } \\
\text { ND } \\
\text { ND } \\
+ \\
\text { ND } \\
+ \\
\text { ND }\end{array}$ & $\begin{array}{l}200-75 \\
45-19 \\
18 \\
16-13 \\
13 \\
13 \\
12-10 \\
10-9 \\
9-8 \\
8 \\
8 \\
8-6 \\
6\end{array}$ & $\begin{array}{c}150 \\
" \\
" \\
\ddot{125} \\
" \\
" \\
" \\
" \\
"\end{array}$ & $\begin{array}{r}110 \\
204 \\
138 \\
\text { ND } \\
104 \\
18 \\
15 \\
20 \\
23 \\
30 \\
82 \\
\text { ND } \\
26\end{array}$ \\
\hline
\end{tabular}

were no longer available, but by 20 August 1970 he was anti-HBe positive and has remained so. The presence of anti-HBe is associated with a reduction in infectivity, but in some series up to one-third of anti-HBe positive carriers have been found to have significant numbers of $\mathbf{4 2} \mathrm{nm}$ virus particles.?

The level of antigenaemia fell sharply during 1973 for no obvious reason, and at the same time the alanine transferase liver function test results moved within the normal range.

In 1979, for the first time, antigen ceased to be detectable by the most sensitive available RIA tests, and a trace of anti-HBs appeared $(0.1 \mathrm{IU} / \mathrm{ml}-\mathrm{DS}$ Dane, personal communication). No $\mathrm{HBs} \mathrm{Ag}$ has now been detected in five sera taken in the first 18 months of $1970-80$, and the patient may be considered no longer antigenaemic for practical purposes.

It is unlikely that his liver is free from infection, and evidence from the work of Katchaki et al., ${ }^{8}$ who found 'occult' HBs Ag in two RIA-negative individuals, and of Kojima et al., ${ }^{9}$ who found that high anti-HBc titres were associated with infected hepatocytes, suggests that an increase in immunosuppressive therapy might still cause reversion to antigenaemia.

Nevertheless it is felt that this case history has provided a unique illustration of the course of antigenaemia during long-term immunosuppression for the maintenance of a renal allograft.

I am indebted to Professor RY Calne and Dr DB Evans for clinical details and helpful dis- cussions, and also to Dr DS Dane for some of the serological tests.

\section{References}

1 Nagington J. Chronic carriage of Australia antigen without symptoms after renal transplant. Br MedJ 1970 ;iv :409-10.

- Cayzer I, Dane DS, Cameron CH, Denning JV. A rapid haemagglutination test for hepatitis-B antigen. Lancet $1974 ; i: 947-9$.

3 Vandervelde EM, Mahmood N, Goffin C, Porter A, Megson B, Cossart YE. User's guide to some new tests for hepatitis-B antigen. Lancet 1974 ;ii :1066-8.

- Almeida JD, Zuckerman AJ, Taylor PE, Waterson AP. Immune electron microscopy of the Australia-SH (serum hepatitis) antigen. Microbios 1969;2:117-23.

${ }^{5}$ Hoofnagle JH, Gerety RJ, Ni LY, Barker LF. Antibody to hepatitis-B virus core in man. Lancet 1973;ii:869-73.

- Nagington J, Cossart YE, Cohen BJ. Reactivation of hepatitis B after transplantation operations. Lancet 1977 ; i:558-60.

${ }^{7}$ Trepo C, Bird RG, Zuckerman AJ. Correlations between the detection of $e$ antigen or antibody and electron microscopic pattern of hepatitis B surface antigen (HBs Ag) associated particles in the serum of HBs Ag carriers. J Clin Pathol 1977;30:216-7.

${ }^{8}$ Katchaki JN, Siem TH, Brouwer R. Serological evidence of presence of $\mathrm{HBs} \mathrm{Ag}$ undetectable by conventional radioimmunoassay in anti-HBc positive blood donors. $J$ Clin Pathol 1978;31:837-9.

- Kojima M, Udo K, Takahashi Y, et al. Correlation between titer of antibody to hepatitis B core antigen and presence of viral antigens in the liver. Gastroenterology 1977;73:664-7.

Requests for reprints to: Dr J Nagington, Public Health Laboratory Service, Level 6, Laboratory Block, Addenbrooke's Hospital, Cambridge CB2 2QW. 